\title{
PENGARUH LOYALITAS, KOMITMEN DAN BUDAYA ORGANISASI TERHADAP KINERJA PEGAWAI PADA BIRO HUMAS DAN KEPROTOKOLAN SEKRETARIAT DAERAH PROVINSI SUMATERA UTARA
}

\author{
Dessy Wahyuni \\ Universitas Islam Sumatera Utara \\ dessy.wahyuni@gmail.com
}

\begin{abstract}
This research aims to find out the influence jointly or partially between loyality, commitment and organizational culture to the performance of the Workers at the Public Relations and Protocol Bureau Regional Secretariat Of North Sumatera. This research uses descriptive qualitative method using primary and secondary data. The population is the workers of the company. Sixty five workers become the sample of this research. Data analysis technique used is linear regression which shows that from the three independent variables applied to the regression model (loyality, commitment and organizational culture). Loyality is significant for 0,073 which can be concluded that loyality not affects performance (hypothesis 1 rejected). Commitment has significant value 0,000 which can be concluded that commitment affects performance (hypothesis 2 accepted). Organizational culture variable has significant value 0,002 which means that organizational culture affects performance (hypothesis 3 accepted). Research results show that loyality, commitment and organizational culture all positively influence the performance of the workers. It can be proven using the result of regression statistic test with probability value 0,000 obtained which is lower than $\alpha(\alpha=0,05)$. So, it can be said that loyality, commitment and organizational culture influence positively the performance of the workers. Thus, hypothesis 4 accepted.
\end{abstract}

Keywords :Loyality, Commitment, Organizational Culture and Performance

ABSTRAK : Penelitian ini bertujuan untuk mengetahui pengaruh baik secara bersama-sama maupun parsial antara loyalitas, komitmen dan budaya organisasi terhadap kinerja pegawai di Biro Humas dan Keprotokolan Sekretariat Daerah Provinsi Sumatera Utara. Penelitian ini menggunakan metode kuantitatif dengan jenis penelitian penjelasan (explanatory research) dengan menggunakan data primer dan data sekunder. Populasi dalam penelitian ini adalah pegawai di Biro Humas dan Keprotokolan Sekretariat Daerah Provinsi Sumatera Utara dan sebanyak 65 orang pegawai dijadikan sampel penelitian. Adapun teknik analisis data yang digunakan adalah regresi linear berganda dan parsial dengan menggunakan SPSS 24.0. Hasil analisis regresi menunjukkan bahwa dari ke tiga variabel independen yang dimasukkan kedalam model regresi (loyalitas, komitmen dan budaya organisasi). Variabel loyalitas signifikan pada 0,073 sehingga dapat disimpulkan bahwa kinerja tidak dapat dipengaruhi oleh loyalitas (hipotesis 1 ditolak). Variabel komitmen yang memiliki nilai signifikan pada 0,000. Sehingga dapat disimpulkan bahwa komitmen mempengaruhi kinerja (hipotesis 2 diterima). Variabel budaya organisasi yang memiliki nilai signifikan pada 0,002. Sehingga dapat disimpulkan bahwa budaya organisasi berpengaruh terhadap kinerja pegawai (hipotesis 3 diterima). Hasil penelitian menunjukkan bahwa variabel loyalitas, komitmen dan budaya organisasi secara bersama-sama berpengaruh positif terhadap kinerja pegawai. Hal ini dibuktikan dengan hasil statistik uji regresi diperoleh nilai dengan probabilitas 0,000 lebih kecil dari $\alpha(\alpha=0,05)$ maka dapat dijelaskan bahwa loyalitas, komitmen dan budaya organisasi berpengaruh positif terhadap kinerja pegawai. Maka hipotesis keempat diterima.

Kata Kunci: $\quad$ Loyalitas, Komitmen, Budaya Organisasi dan Kinerja Pegawai 


\section{Pendahuluan}

Pemberlakuan otonomi daerah sesuai dengan Undang - Undang No. 23 Tahun 2014 tentang pemerintah daerah diharapkan dapat memberikan keleluasaan kepada daerah dalam membangun daerah melalui usaha-usaha yang sejauh mungkin mampu meningkatkan kemandirian daerah melalui peningkatan sumber daya alam (SDA) dan peningkatan sumber daya manusia (SDM). Pembangunan nasional dilaksanakan dalam rangka membangun masyarakat Indonesia seutuhnya. Sasaran umum pembangunan nasional pada era globalisasi dan reformasi adalah menciptakan kualitas manusia dan kualitas masyarakat Indonesia yang maju dan mandiri dalam suasana tentram, sejahtera lahir dan batin, dalam tata kehidupan masyarakat, bangsa dan negara yang berdasarkan Pancasila dalam suasana kehidupan bangsa Indonesia yang berkesinambungan.

Untuk mewujudkan pembangunan nasional tentu membutuhkan berbagai sumber daya. Sumber daya manusia mempunyai peranan penting dalam meningkatkan pembangunan, karena memiliki bakat, tenaga dan kreativitas yang sangat dibutuhkan untuk menggerakkan pembangunan. Perlu disadari bahwa sumber daya manusia adalah sumber daya yang terlibat langsung dalam menjalankan kegiatan organisasi maupun instansi. Oleh sebab itu organisasi maupun instansi harus mampu memberikan perhatian secara maksimal pada sumber daya manusianya, baik perhatian dari segi kualitas pengetahuan dan keterampilan, maupun tingkat kesejahteraannya, sehingga terdorong untuk memberikan segala kemampuan sesuai dengan yang dibutuhkan.

Salah satu persoalan penting dalam organisasi adalah pengelolaan sumber daya manusia dalam organisasi, di mana pengelolaan tersebut tentunya menekankan pada tujuan organisasi. Tujuan organisasi dapat tercapai manakala unsur-unsur dalam organisasi tersebut mendukungnya, termasuk kinerja pegawai yang ada dalam organisasi. Kinerja pegawai merupakan salah satu tujuan organisasi yang harus dicapai, karena keberhasilan organisasi dapat ditentukan oleh kinerja individu yang dimiliki organisasi tersebut yang dapat diketahui melalui penilaian dan itu sangat penting. Penilaian kinerja dikatakan penting mengingat melalui penilaian kinerja dapat diketahui seberapa tepat pegawai telah menjalankan fungsinya. Ketepatan pegawai dalam menjalankan fungsinya akan sangat berpengaruh terhadap pencapaian kinerja organisasi secara keseluruhan.

Biro Humas dan Keprotokolan Sekretariat Daerah Provinsi Sumatera Utara merupakan perangkat kerja daerah, yang tugas pokok dan fungsinya adalah melaksanakan pemberitaan, mengumpulkan dan menganalisa informasi untuk bahan kebijakan pimpinan, melakukan perekaman, penyajian data, dan mengatur keprotokoleran kegiatan pimpinan serta melaksanakan tugas lain yang diberikan oleh sekretariat daerah sesuai dengan bidang tugasnya.

Agar tugas pokok dan fungsi di bagian humas dan protokol terlaksana secara optimal, maka sangat diperlukan aparatur atau pegawai yang produktif. Dengan aparatur atau pegawai yang produktif serta diharapkan lebih menjamin seluruh pekerjaan pada biro Humas dan Protokol agar dapat mencapai tujuan yang telah ditetapkan.

Salah satu faktor yang dapat meningkatkan kinerja adalah loyalitas kerja. Menurut Soegandi et al (2013:3) loyalitas kerja atau kesetiaan merupakan salah satu unsur yang digunakan dalam penilaian karyawan yang mencakup kesetiaan terhadap pekerjaannya, jabatannya dan organisasi Loyalitas kerja di Biro Humas dan Keprotokolan Sekretariat Daerah Provinsi Sumatera Utara dapat dilihat dari adanya beberapa pegawai yang masih kurang bertanggung jawab terhadap tugas yang diberikan, hal ini dapat dilihat dari prilaku pegawai pada jam-jam kerja suka melalaikan pekerjaan seharusnya harus sesuai dengan jam kerja yang telah ditentukan, kurangnya bimbingan yang dilakukan terhadap loyalitas/kesetiaan pegawai, kurangnya arahan yang diberikan atasan terhadap bawahannya dalam melaksanakan tanggung jawab.

Selanjutnya untuk meningkatkan kinerja hendaknya memperhatikan komitmen. Sopiah (2008:155) medefenisikan komitmen organisasional merupakan dimensi perilaku penting yang dapat digunakan untuk menilai kecenderungan karyawan untuk bertahan sebagai anggota organisasi. Membangun komitmen organisasional seharusnya menjadi aspek penting yang diperhatikan oleh Pemerintah Sumatera Utara karena dengan adanya komitmen organisasional pegawai maka pegawai tersebut akan memiliki kedekatan terhadap organisasi yang direfleksikan dalam bentuk kekuatan, keterlibatan dan kesetiaan 
pegawai pada organisasi. Komitmen pada organisasi tersebut juga membahas kedekatan pegawai terhadap organisasi di mana mereka berada dan sekaligus komitmen merefleksikan kekuatan keterlibatan dan kesetiaan pegawai pada organisasi. Keterlibatan dan kesetiaan ini sangat dipengaruhi oleh seberapa besar pekerjaan yang dibebankan pada pegawai sesuai dengan harapan mereka.

Faktor lain yang dapat meningkatkan kinerja adalah budaya organisasi. Stoner dan Gilbert (2012:54) menjelaskan bahwa budaya organisasi didefinisikan sebagai norma, nilai, dan pemahaman yang dimiliki bersama (budaya) dari anggota beberapa organisasi yang mendukung pengendalian yang ketat dipuncak.

Budaya Organisasi dalam diri pegawai sendiri seperti halnya memberikan kesempatan mengambil inisiatif dalam pelaksanaan tugastugas sehari-hari belum membudaya dan belum tumbuh sehingga beberapa pegawai dalam melaksanakan tugas kantor masih menunggu arahan, perintah dukungan pimpinan pada levelnya masing-masing. Selain itu budaya memberi penghargaan bagi pegawai yang berprestasi kurang membudaya, budaya mentaati kesepakatan-kesepakatan yang telah dibuat kurang di taati, serta budaya saling menghargai perbedaan pendapat kurang membudaya.

Berdasarkan permasalahan yang terjadi diatas maka penulis tertarik melakukan penelitian dengan judul: "Pengaruh Loyalitas, Komitmen dan Budaya Organisasi terhadap Kinerja Pegawai Pada Biro Humas dan Keprotokolan Sekretariat Daerah Provinsi Sumatera Utara".

Adapun tujuan penelitian ini adalah :

a. Untuk mengetahui pengaruh loyalitas terhadap kinerja pegawai Biro Humas dan Keprotokolan Sekretariat Daerah Provinsi Sumatera Utara.

b. Untuk mengetahui pengaruh komitmen terhadap kinerja pegawai Biro Humas dan Keprotokolan Sekretariat Daerah Provinsi Sumatera Utara.

c. Untuk mengetahui pengaruh budaya organisasi terhadap kinerja pegawai Biro Humas dan Keprotokolan Sekretariat Daerah Provinsi Sumatera Utara.

d. Untuk mengetahui pengaruh loyalitas, komitmen dan budaya organisasi terhadap kinerja pegawai Biro Humas dan Keprotokolan Sekretariat Daerah Provinsi Sumatera Utara.

\section{Metode Penelitian}

\subsection{Lokasi Penelitian}

Penelitian ini dilakukan di Biro Humas dan Keprotokolan Sekretariat Daerah Provinsi Sumatera Utara yang beralamat di Jalan Pangeran Diponegoro No. 30, Madras Hulu, Kec. Medan Polonia, Kota Medan, Sumatera Utara 20151.

\subsection{Populasi}

Populasi adalah wilayah generalisasi yang terdiri atas: obyek/subyek yang mempunyai kualitas dan karakteristik tertentu yang ditetapkan oleh peneliti untuk dipelajari dan kemudian ditarik kesimpulannya, Sugiyono (2011:80). Populasi dalam penelitian ini adalah seluruh pegawai Biro Humas dan Keprotokolan Sekretariat Daerah Provinsi Sumatera Utara 65 orang.

\subsection{Sampel}

Sampel adalah bagian dari jumlah dan karakteristik yang dimiliki oleh populasi tersebut, Sugiyono (2006:118). Dikarenakan jumlah populasi relatif sedikit, maka dalam pengambilan jumlah sampel dalam penelitian ini peneliti mengambil seluruh jumlah populasi untuk dijadikan sampel. maka besarnya sampel pada penelitian ini adalah 65 orang.

\subsection{Operasional Variabel}

Variabel penelitian adalah segala sesuatu yang berbentuk apa saja yang ditetapkan oleh peneliti untuk dipelajari sehingga diperoleh informasi tentang hal tersebut, kemudian ditarik kesimpulannya, Sugiyono (2016:38).

Operasional variabel dimaksudkan untuk mengetahui seberapa besar pengaruh suatu variabel terhadap variabel lainnya. Operasional variabel adalah suatu defenisi yang diberikan kepada suatu variable dengan cara memberikan arti atau menspesifikasikan kegiatan atau mengukur variabel tersebut. dalam penelitian ini penulis mengidentifikasi ada dua variabel penelitian, yaitu :

a. Variabel bebas (independent variable), yaitu : merupakan variabel yang menjadi sebab berubahnya atau timbulnya variabel terikat, Sugiono (2001:21) yang dinyatakan dengan $\mathrm{X}$ (Loyalitas (X1), Komitmen (X2) dan Budaya Organisasi (X3).

b. Variable terikat (dependent variable), yaitu : merupakan variabel yang dipengaruhi atau yang menjadi akibat Karena adanya variabel 
bebas, (Sugiono 2001:21) yang dinyatakan dengan Y (Kinerja Pegawai).

\subsection{Teknik Analisis Data}

\subsubsection{Uji Kualitas Data}

Pengujian kualitas data dalam penelitian ini menggunakan uji validitas dan reliabilitas, yaitu:

a. Uji Validitas

Pengujian validitas dilakukan untuk menguji apakah instrumen penelitian yang telah disusun benar-benar akurat, sehingga mampu mengukur apa yang seharusnya diukur (variabel kunci yang sedang diteliti). Umar (2008:88) menyatakan uji validitas berguna untuk mengetahui apakah ada pertanyaanpertanyaan kuesioner yang harus dibuang/diganti karena dianggap tidak relevan. Validitas dalam hal ini merupakan akurasi temuan penelitian yang mencerminkan kebenaran sekalipun responden yang dijadikan objek pengujian berbeda, Ikhsan dan Ghozali (2006:76).

Pada penelitian ini pengujian dilakukan dengan program SPSS, dan untuk uji validitas dengan menggunakan korelasi Bivariate Pearson (Produk Momen Pearson) dan Corrected Item-Total Correlation. Priyatno (2008:90) mengemukakan kriteria pengujiannya dengan taraf signifikansi $5 \%$ atau 0,05 yaitu Jika $r$ hitung $\geq r$ tabel maka instrumen pertanyaan-pertanyaan kuesioner berkorelasi terhadap skor total (dinyatakan valid), dan jika $r$ hitung < r tabel maka instrumen pertanyaan-pertanyaan kuesioner tidak berkorelasi signifikan terhadap skor total (dinyatakan tidak valid).

b. Uji Reliabilitas

Pengujian reliabiltas dilakukan setelah pengujian validitas instrumen penelitian. Uji reliabilitas digunakan untuk mengetahui konsistensi alat ukur, apakah alat pengukur yang digunakan dapat diandalkan dan tetap konsisten jika pengukuran tersebut diulang. Umar (2008:105) mengatakan pengujian reliabilitas berguna untuk mengetahui apakah instrumen yang dalam hal ini kuesioner dapat digunakan lebih dari satu kali, paling tidak oleh responden yang sama.
Dalam melakukan uji reliabilitas digunakan metode Cronbach's Alpha dengan bantuan program SPSS, menurut Priyatno (2008:102) menyebutkan metode alpha sangat cocok digunakan pada skor berbentuk skala. Santosa (2005:112) mengatakan suatu kuesioner dikatakan reliabel jika Cronbach Alpha lebih besar dari 0,6.

\subsubsection{Uji Asumsi Klasik}

Uji asumsi klasik dilakukan untuk mengetahui apakah sampel yang ditetapkan telah dapat dilakukan analisis dan melihat apakah model prediksi yang dirancang telah dapat dimasukkan kedalam serangkaian data, maka perlu dilakukan pengujian data.

a. Uji Normalitas

Menurut Priyatno (2012:144) pengertian dari uji normalitas adalah untuk menguji apakah nilai residual yang dihasilkan dari regresi terdistribusi secara normal atau tidak. Model regresi yang baik adalah yang memiliki nilai residual yang terdistribusi normal.

Salah satu cara termudah untuk melihat normalitas adalah dengan melihat histogram yang membandingkan antara data observasi dengan distribusi yang mendekati distribusi normal. Model regresi yang baik adalah yang memiliki distribusi data normal atau mendekati normal. Artinya kriteria berdistribusi normal apabila tampilan grafiknya menunjukkan pola penyebaran disekitar garis diagonal dan mengikuti arah garis diagonal, uji normalitas dilakukan dengan mengamati penyebaran data pada sumbu diagonal grafik. Metode yang dipakai adalah plot. Cara pengambilan keputusan pada metode plot adalah:

1) Jika data menyebar disekitar garis diagonal dan mengikuti arah garis diagonal, maka model garis regresi memenuhi asumsi normalitas.

2) Jika data menyebar jauh dari garis diagonal atau tidak mengikuti arah garis diagonal, maka model regresi tidak memenuhi asumsi normalitas.

b. Uji Multikolinearitas

Menurut Priyatno (2012:151) pengertian multikolinieritas adalah keadaan di mana pada model regresi ditemukan adanya korelasi yang sempurna atau mendekati sempurna antar variabel independen. Pada regresi yang baik seharusnya tidak terjadi 
korelasi yang sempurna atau mendekati sempurna diantara variabel bebas. Untuk mendeteksi ada tidaknya multikolinearitas didalam model regresi dapat dilihat dari nilai tolerance dan lawannya. Cara yang digunakan untuk mendeteksi ada tidaknya multikolinieritas adalah dengan melihat besarnya nilai variance inflation factor (VIF). Jika VIF dibawah 10 dan Tolerance Value diatas 0,1 maka tidak terjadi multikolinieritas.

c. Uji Heteroskedastisitas

Uji ini dilakukan untuk menguji apakah dalam model regresi ini terjadi ketidaksamaan variance dari residual satu pengamatan ke pengamatan lainnya. Jika variance dari residual pengamatan ke pengamatan lain tetap, maka disebut homoskedastisitas dan jika berbeda disebut heteroskedastisitas. Model regresi yang baik adalah yang homoskedastisitas atau tidak terjadi heteroskedastisitas.

1) Jika ada pola tertentu, serta titik-titik yang ada membentuk pola tertentu yang teratur (bergelombang, melebar kemudian menyempit) maka mengindikasikan telah terjadi heteroskedastisitas.

2) Jika tidak ada pula yang jelas, serta titik-titik menyebar diatas dan dibawah angka 0 pada sumbu Y, maka tidak terjadi heteroskedastisitas.

\subsection{Analisis regresi berganda}

Dalam penelitian ini model data menggunakan analisis regresi berganda. Model ini dipilih untuk mengetahui besarnya pengaruh variabel loyalitas, komitmen, budaya organisasi dan kinerja pegawai. Dalam suatu penelitian, kemungkinan munculnya masalah dalam analisis regresi cukup sering dalam mencocokan model prediksi ke dalam sebuah model yang dimasukan kedalam serangkaian data.

Persamaan regresi linear berganda dalam penelitian ini adalah sebagai berikut:

Keterangan:

$$
\mathbf{Y}=\mathbf{a}+\mathbf{b}_{1} \mathbf{X}_{1}+\mathbf{b}_{2} \mathbf{X}_{2}+\mathbf{b}_{3} \mathbf{X}_{3}+\mathbf{e}
$$

$\mathrm{Y}=$ Kinerja pegawai

$\mathrm{X}_{1}=$ Loyalitas

$\mathrm{X}_{2}=$ Komitmen

$\mathrm{X}_{3}=$ Budaya organisasi

$\mathrm{a}=$ Konstanta

$\mathrm{b}_{1}=$ Koefisien regresi Loyalitas

$\mathrm{b}_{2}=$ Koefisien regresi Komitmen $b_{3}=$ Koefisien regresi Budaya organisasi

$\mathrm{e}=$ Error

\subsection{Uji Hipotesis}

Uji hipotesis bertujuan untuk mengetahui apakah terdapat pengaruh yang jelas dan dapat dipercaya antara variabel independen (loyalitas, komitmen dan budaya organisasi) terhadap variabel dependen (kinerja pegawai). Pengujian hipotesis menggunakan uji regresi berganda. Dalam analisis regresi, dikembangkan sebuah persamaan regresi yaitu suatu formula yang mencari nilai variabel dependen dari nilai variabel independen yang diketahui.

a. Uji Signifikansi Simultan (Uji F)

Uji statistik $F$ pada dasarnya menunjukkan apakah semua variabel independen yang dimasukkan dalam model mempunyai pengaruh secara simultan atau bersamasama terhadap variabel dependen. Adapun langkah-langkah dalam pengambilan keputusan untuk uji $\mathrm{F}$ adalah dengan melihat nilai signifikan, apabila nilai sig $\alpha<0,05$ maka dapat disimpulkan variabel independen secara simultan atau bersamasama berpengaruh signifikan terhadap variabel dependen atau hipotesis diterima. Begitu juga sebaliknya apabila nilai sig $\alpha>$ 0,05 maka dapat disimpulkan variabel independen secara simultan atau bersamasama tidak berpengaruh signifikan terhadap variabel dependen atau hipotesis ditolak, Ghozali (2016:96). Dengan kaidah pengambilan keputusan :

1. Terima Ho, jika koefisien $F$ hitung signifikan pada taraf lebih besar dari 5\% (lihat taraf signifikansi pada output ANOVA).

2. Tolak Ho, jika koefisien $F$ hitung signifikan pada taraf lebih kecil atau sama dengan 5\% (lihat taraf signifikansi pada output ANOVA).

b. Uji Signifikansi Parsial (Uji t)

Uji statistik t pada dasarnya menunjukkan seberapa jauh satu variabel independen secara individual dalam menerangkan variasi variabel terikat. Uji statistik $t$ digunakan untuk menguji sebarapa jauh pengaruh dari variabel independen secara parsial terhadap variabel dependen atau untuk melihat variabel apa yang memberikan pengaruh dominan diantara variabel yang ada. Adapun langkah-langkah dalam pengambilan keputusan untuk uji $t$ adalah dengan melihat nilai signifikan, 
apabila nilai sig $\alpha<0,05$ maka dapat disimpulkan variabel independen secara parsial berpengaruh signifikan terhadap variabel dependen atau hipotesis diterima. Begitu juga sebaliknya apabila nilai $\operatorname{sig} \alpha>$ 0,05 maka dapat disimpulkan variabel independen secara parsial tidak berpengaruh signifikan terhadap variabel dependen atau hipotesis ditolak, Ghozali (2016:97).

Dengan kaidah pengambilan keputusan :

a. Terima Ho, jika koefisien $t$ hitung signifikan pada taraf lebih besar dari 5\% (lihat taraf signifikansi pada output Coefficien).

b. Tolak Ho, jika koefisien $t$ hitung signifikan pada taraf lebih kecil atau sama dengan 5\% (lihat taraf signifikansi pada output Coefficient).

\subsection{Uji Koefisien Determinasi}

Menurut Nugroho (2005:118) koefisien determinasi $\left(R^{2}\right)$ bertujuan untuk mengetahui seberapa besar kemampuan variabel independen menjelaskan variabel dependen. Dengan bantuan olahan program SPSS koefisien determinasi $\left(R^{2}\right)$ terletak pada tabel model Summary dan tertulis $R$ Square. Namun menurut Nugroho (2005:120) menyebutkan untuk regresi linier berganda sebaiknya menggunakan $R$ Square yang sudah disesuaikan atau tertulis Adjusted $R$ Square karena disesuaikan dengan jumlah variabel independen yang digunakan dalam penelitian. Nilai koefisien determinasi antara 0 dan $1(0<$ $\left.\mathrm{R}^{2}<1\right)$. Nilai yang mendekati satu berarti variabel-variabel independen memberikan hampir semua informasi yang dibutuhkan untuk memprediksi variabel-variabel dependen.

\section{Analisis Dan Pembahasan \\ 3.1. Uji Regresi Linear Berganda}

Untuk mempermudah pembacaan hasil dan interpretasi analisis regresi maka digunakan bentuk persamaan. Persamaan atau model tersebut berisi konstanta dan koefisien-koefisien regresi yang didapat dari hasil pengolahan data yang telah dilakukan sebelumnya.

Tabel 1

Uji Regresi Linier Berganda

Coefficients $^{\mathrm{a}}$

\begin{tabular}{|c|c|c|c|c|c|c|}
\hline \multirow{2}{*}{\multicolumn{2}{|c|}{ Model }} & \multicolumn{2}{|c|}{ Unstandardized Coefficients } & \multirow{2}{*}{$\begin{array}{c}\text { Standardized } \\
\text { Coefficients } \\
\text { Beta } \\
\end{array}$} & \multirow[b]{2}{*}{$\mathrm{t}$} & \multirow[b]{2}{*}{ Sig. } \\
\hline & & $\mathrm{B}$ & Std. Error & & & \\
\hline \multirow[t]{4}{*}{1} & (Constant) & 1.356 & 2.358 & & .575 & .567 \\
\hline & Loyalitas & .174 & .095 & .167 & 1.824 & .073 \\
\hline & Komitmen & .579 & .096 & .603 & 6.012 & .000 \\
\hline & BudayaOrganisasi & .233 & .072 & .229 & 3.222 & .002 \\
\hline
\end{tabular}

a. Dependent Variable: KinerjaPegawai

Persamaan regresi yang telah dirumuskan dilakukan pengolahan data sehingga didapat persamaan akhir yaitu :

$$
Y=1,356+0,174 X_{1}+0,579 X_{2}+0,233 X_{3}
$$

Pada model regresi ini, nilai konstanta yang tercantum sebesar 1,356 dapat diartikan jika variabel bebas dalam model diasumsikan sama dengan nol atau variabel bebas dalam hal ini loyalitas, komitmen dan budaya organisasi diterapkan, maka kinerja pegawai akan mengalami kenaikan sebesar 1,356 satuan.

Nilai besaran koefisien regresi $\beta_{1}$ sebesar 0,174 pada penelitian ini dapat diartikan bahwa variabel loyalitas $\left(\mathrm{X}_{1}\right)$ tidak berpengaruh terhadap kinerja pegawai (Y). Hal ini menunjukkan bahwa ketika variabel loyalitas terpenuhi, maka kinerja pegawai tidak akan baik/tinggi.

Nilai besaran koefisien regresi $\beta_{2}$ sebesar 0,579 pada penelitian ini dapat diartikan bahwa variabel komitmen $\left(\mathrm{X}_{2}\right)$ berpengaruh positif terhadap kinerja pegawai (Y). Hal ini menunjukkan bahwa ketika variabel komitmen terpenuhi, maka kinerja pegawai akan naik/baik.

Nilai besaran koefisien regresi $\beta_{3}$ sebesar 0,233 pada penelitian ini dapat diartikan bahwa variabel budaya organisasi $\left(\mathrm{X}_{3}\right)$ berpengaruh terhadap kinerja pegawai $(Y)$. Hal ini menunjukkan bahwa ketika budaya organisasi terpenuhi, maka kinerja pegawai akan baik/tinggi. 


\subsection{Pengujian Hipotesis}

Untuk menguji hipotesis mengenai pengaruh loyalitas, komitmen dan budaya organisasi terhadap kinerja pegawai secara simultan dan parsial digunakan pengujian hipotesis secara simultan dengan uji $\mathrm{F}$ dan secara parsial dengan uji t.

\subsubsection{Pengujian Hipotesis dengan Uji t}

Nilai dari uji t hitung dapat dilihat dari pvalue (pada kolom Sig.) pada masing-masing variabel independen, jika p-value lebih kecil dari level of significant yang ditentukan atau $\mathrm{t}$ hitung (pada kolom $\mathrm{t}$ ) lebih besar dari t tabel (dihitung dari two-tailed $\alpha=5 \%$ df-k, $\mathrm{k}$ merupakan jumlah variabel independen dan dependen), maka nilai variabel independen secara parsial berpengaruh signifikan terhadap variabel dependen (dalam arti Ha diterima dan Ho ditolak, dengan kata lain, terdapat pengaruh antara variabel independen terhadap variabel dependen).

Adapun metode dalam penentuan $t$ tabel menggunakan ketentuan tingkat signifikan $5 \%$, dengan $\mathrm{df}=n-k-1$ (pada penelitian ini $\mathrm{df}=65-4$ $-1=60$ ), sehingga didapat nilai $t$ tabel sebesar 2,000 disajikan dalam tabel 5.10 sebagai berikut:

Tabel 2

Uji Parsial (Uji t)

Coefficients $^{\mathrm{a}}$

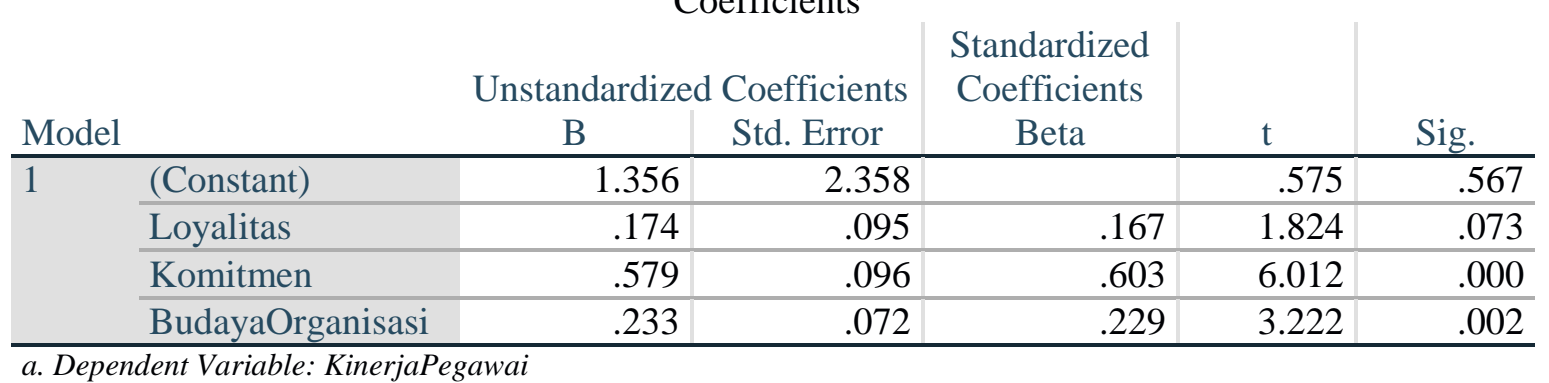

Berdasarkan tabel di atas, diketahui nilai $t$ hitung dari masing-masing variabel independen dan variabel dependen yaitu :

a. Variabel loyalitas memiliki nilai p-value (pada kolom Sig.) 0,073>0,05 artinya tidak signifikan, sedangkan thitung $1,824<$ dari $\mathrm{t}$ tabel 2,000 artinya tidak signifikan. Hal ini berarti bahwa loyalitas tidak berpengaruh terhadap kinerja pegawai.

b. Variabel komitmen memiliki nilai p-value (pada kolom Sig.) $0,000<0,05$ artinya signifikan, sedangkan $\mathrm{t}$ hitung $6,012>$ dari $\mathrm{t}$ tabel 2,000 artinya signifikan. Hal ini berarti bahwa komitmen berpengaruh terhadap kinerja pegawai.

c. Variabel budaya organisasi memiliki nilai $p$ value (pada kolom Sig.) 0,002 <0,05 artinya signifikan, sedangkan $\mathrm{t}$ hitung 3,222 > dari $\mathrm{t}$ tabel 2,000 artinya signifikan. Hal ini berarti bahwa budaya organisasi berpengaruh signifikan terhadap kinerja pegawai.

\subsubsection{Pengujian Hipotesis dengan Uji $F$}

Hasil uji F menunjukan variabel independen secara bersama-sama berpengaruh terhadap variabel dependen, jika $p$-value (pada kolom sig.) lebih kecil dari level of significant yang ditentukan (sebesar $5 \%$ ), atau F hitung (pada kolom $\mathrm{F}$ ) lebih besar dari $\mathrm{F}$ tabel. $\mathrm{F}$ tabel dihitung dengan cara df $1=\mathrm{k}-1$, dan df $2=\mathrm{n}-\mathrm{k}$, yaitu df $1=4-1=3$ dan df $2=65-4=61$, sehingga didapat nilai $\mathrm{F}$ tabel sebesar 2.76 . Sedangkan hasil uji $\mathrm{F}$ dengan bantuan program SPSS dapat dilihat pada tabel di bawah ini:

Tabel 3

Hasil Uji Simultan (Uji F)

\begin{tabular}{|c|c|c|c|c|c|c|}
\hline \multirow[b]{2}{*}{ Model } & \multicolumn{6}{|c|}{ ANOVA $^{\mathrm{a}}$} \\
\hline & & $\begin{array}{l}\text { Sum of } \\
\text { Squares }\end{array}$ & $\mathrm{df}$ & Mean Square & $\mathrm{F}$ & Sig. \\
\hline \multirow[t]{3}{*}{1} & Regression & 496.034 & 3 & 165.345 & 79.161 & $.000^{\mathrm{b}}$ \\
\hline & Residual & 127.412 & 61 & 2.089 & & \\
\hline & Total & 623.446 & 64 & & & \\
\hline
\end{tabular}


Berdasarkan uji $\mathrm{F}$ atau uji Anova atau uji simultan di atas diperoleh $\mathrm{F}$ hitung sebesar 79,161 pada $\alpha=5 \%$ atau 0,05 dengan tingkat signifikan 0,000 ., karena nilai probabilitas $(0,000)$ jauh lebih kecil dari 0,05 maka model regresi dapat dipakai untuk memprediksi bahwa loyalitas (x1), komitmen (x2) dan budaya organisasi (x3) sebagai variabel independen secara bersama-sama (simultan) berpengaruh terhadap kinerja pegawai (Y). Dengan kata lain, loyalitas (x1), komitmen (x2) dan budaya organisasi (x3) secara simultan mempunyai pengaruh yang positif dan signifikan terhadap kinerja pegawai, karena $\mathrm{F}$ hitung $>\mathrm{F}$ tabel yakni 79,161 > 2,76. Hal tersebut berarti jika loyalitas (x1), komitmen (x2) dan budaya organisasi (x3) secara bersama-sama diterapkan di dalam organisasi maka akan berdampak pada kenaikan kinerja pegawai (Y), sebaliknya jika loyalitas (x1), komitmen (x2) dan budaya organisasi (x3) secara bersama-sama tidak diterapkan maka akan berdampak pada penurunan kinerja pegawai $(\mathrm{Y})$.

\subsection{Analisis Koefisien Determinasi $\left(\boldsymbol{R}^{2}\right)$}

Dengan bantuan olahan program SPSS koefisien determinasi $\left(R^{2}\right)$ terletak pada tabel model Summary dan tertulis $R$ Square. Untuk regresi linier berganda sebaiknya menggunakan $R$ Square yang sudah disesuaikan atau tertulis Adjusted $R$ Square karena disesuaikan dengan jumlah variabel independen yang digunakan dalam penelitian. Nilai $R$ Square/Adjusted $R$ Square dikatakan baik jika di atas 0,5 karena nilai $R$ Square berkisar antara 0 sampai dengan 1. Hasil analisis koefisien determinasi dalam penelitian ini dapat dilihat pada berikut ini :

Tabel 4

Hasil Analisis Koefisien Determinasi

Model Summary

\begin{tabular}{lr|r|r|r} 
Model & R & R Square & $\begin{array}{c}\text { Adjusted R } \\
\text { Square }\end{array}$ & $\begin{array}{l}\text { Std. Error of } \\
\text { the Estimate }\end{array}$ \\
\hline 1 & $.892^{\mathrm{a}}$ & .796 & .786 & 1.445 \\
\hline
\end{tabular}

a. Predictors: (Constant), BudayaOrganisasi, Loyalitas, Komitemen

Hasil olahan pada tabel di atas terlihat nilai koefisien determinasi $\left(R^{2}\right)$ yang sudah disesuaikan (Adjusted $R$ Square) sebesar 0,786. Artinya 78,6\% variabel dependen (kinerja pegawai) dipengaruhi atau dijelaskan oleh variabel independen yaitu loyalitas, komitmen dan budaya organisasi dan sisanya sebesar $21,4 \% \quad(100 \%-78,6 \%)$ dipengaruhi atau dijelaskan oleh variabel lain di luar variabel yang digunakan dalam penelitian ini.

\section{Evaluasi}

4.1. Pengaruh Loyalitas, Komitmen dan Budaya Organisasi secara simultan terhadap Kinerja Pegawai.

Pada pengujian hipotesis berdasarkan hasil perhitungan dapat dikatakan bahwa loyalitas, komitmen dan budaya organisasi secara simultan berpengaruh positif dan signifikan terhadap kinerja pegawai. Dengan demikian secara simultan hasil penelitian ini telah sesuai dengan teori yang menyatakan bahwa loyalitas, komitmen dan budaya organisasi signifikan terhadap kinerja pegawai.

Pengaruh positif dan signifikan loyalitas, komitmen dan budaya organisasi diterapkan di Biro Humas dan Keprotokolan Sekretariat Daerah Provinsi Sumatera Utara, maka akan meningkatkan kinerja pegawai. Artinya bahwa loyalitas, komitmen dan budaya organisasi memiliki perananan yang penting dalam meningkatkan kinerja pegawai. Hal ini juga menunjukkan bahwa pegawai merasa mampu menyelesaikan semua tugas sesuai dengan jumlah yang diharapkan perusahaan, mampu menyelesaikan tugas sesuai dengan target, selalu mencapai target yang ditetapkan oleh perusahaan, Bekerja sama dengan tim untuk memenuhi target, jarang membuat kesalahan ketika bekerja, memegang erat sistem pendelegasian wewenang, tugas dan tanggung jawab yang ditetapkan perusahaan, dapat bekerja dengan baik dalam team, dapat menyerahkan laporan kepada atasan tepat pada waktunya.

\subsection{Pengaruh Loyalitas Terhadap Kinerja Pegawai}

Secara parsial hasil penelitian ini menunjukan bahwa loyalitas berpengaruh terhadap kinerja pegawai. Dengan kata lain terpenuhinya loyalitas di Biro Humas dan Keprotokolan Sekretariat Daerah Provinsi Sumatera Utara akan berpengaruh terhadap kinerja pegawai. Hal ini menunjukkan bahwa loyalitas diperlukan dan penting untuk 
diterapkan di Biro Humas dan Keprotokolan Sekretariat Daerah Provinsi Sumatera Utara.

Hal ini terbukti dari jawaban responden yang rata-rata setuju bahwa selalu mengikuti peraturan yang ditetapkan perusahaan, akan menghabiskan sisa karir anda di organisasi ini, bersedia melakukan usaha yang maksimal untuk kesuksesan organisasi ini, merasa bangga ketika perusahaan mendapatkan kemajuan, tetap akan bertahan diperusahaan meskipun perusahaan mengalami kemajuan atau kemunduran, akan melakukan usaha ekstra untuk memajukan organisasi ini, alasan saya tetap bertahan karena kesetiaan dan pengabdian pada perusahaan, senantiasa menaati jam kerja yang telah ditentukan.

\subsection{Pengaruh Komitmen Terhadap Kinerja Pegawai}

Secara parsial hasil penelitian ini menunjukan bahwa komitmen berpengaruh terhadap kinerja pegawai. Dengan kata lain terpenuhinya komitmen di Biro Humas dan Keprotokolan Sekretariat Daerah Provinsi Sumatera Utara akan berpengaruh terhadap kinerja pegawai. Hal ini menunjukkan bahwa komitmen diperlukan dan penting untuk diterapkan di Biro Humas dan Keprotokolan Sekretariat Daerah Provinsi Sumatera Utara.

Hal ini terbukti dari jawaban responden yang rata-rata setuju bahwa merasa senang untuk menghabiskan karir saya di organisasi ini, merasa bangga menjadi bagian di organisasi ini, merasa seolah-olah masalah organisasi menjadi masalah pribadi, Jika saya ditawari untuk pekerjaan yang lebih baik di tempat lain, saya tidak akan meninggalkan perusahaan ini, Perusahaan ini berarti sangat besar bagi saya, Akan sangat berat bagi saya meninggalkan perusahaan ini, Kehidupan saya akan terganggu bila meninggalkan perusahaan ini sekarang, selalu setia pada perusahaan yang merupakan kewajiban moral.

\subsection{Pengaruh Budaya Organisasi Terhadap Kinerja Pegawai}

Secara parsial hasil penelitian ini menunjukan bahwa budaya organisasi tidak berpengaruh terhadap kinerja pegawai. Pengaruh tersebut menunjukkan bahwa budaya organisasi tidak searah dengan kinerja pegawai atau dengan kata lain terpenuhinya budaya organisasi tidak akan berpengaruh terhadap kinerja pegawai yang baik/tinggi. Pengaruh tersebut menunjukkan bahwa budaya organisasi tidak mempunyai peranan yang penting dalam meningkatkan kinerja pegawai di Biro Humas dan Keprotokolan Sekretariat Daerah Provinsi Sumatera Utara.

Hal ini terbukti dari jawaban responden yang rata-rata tidak setuju bahwa Bila terjadi permasalahan kerja saya berusaha untuk mencari penyebabnya, Bila terjadi permasalahan saya mendiskusikan dengan pegawai lain untuk menyelesaikannya, hasil kerja yang maksimal menjadi tujuan saya dalam bekerja, dalam bekerja saya selalu memperhatikan semua kepentingan pegawai, demi tercapainya tujuan organisasi setiap pegawai harus saling membantu dalam melaksanakan tugasnya, dapat memanfaatkan fasilitas kerja untuk membantu menyelesaikan pekerjaan, berusaha agar hasil pekerjaan yang saya lakukan diatas standar organisasi, tetap berusaha mempertahankan kerja terbaik saya walaupun mengalami kesulitan.

\section{Kesimpulan}

Penelitian ini bertujuan untuk melihat pengaruh loyalitas, komitmen dan budaya organisasi terhadap kinerja pegawai baik secara simultan maupun parsial. Hasil penelitian ini memberikan kesimpulan sebagai berikut :

a. Loyalitas, komitmen dan budaya organisasi secara simultan berpengaruh positif dan signifikan terhadap kinerja pegawai di Biro Humas dan Keprotokolan Sekretariat Daerah Provinsi Sumatera Utara.

b. Loyalitas secara parsial berpengaruh terhadap kinerja pegawai di Biro Humas dan Keprotokolan Sekretariat Daerah Provinsi Sumatera Utara.

c. Kompitmen secara parsial berpengaruh terhadap kinerja pegawai di Biro Humas dan Keprotokolan Sekretariat Daerah Provinsi Sumatera Utara.

d. Budaya organisasi secara parsial berpengaruh terhadap kinerja pegawai di Biro Humas dan Keprotokolan Sekretariat Daerah Provinsi Sumatera Utara.

e. Kinerja pegawai sebesar $78,6 \%$ dipengaruhi oleh loyalitas, komitmen dan budaya organisasi, sedangkan sisanya sebesar $21,4 \%$ dipengaruhi oleh variabel lain di luar model.

\section{DAFTAR PUSTAKA}

A.A. Anwar Prabu Mangkunegara. (2013). Manajemen Sumber Daya Manusia Perusahaan. Bandung: PT. Remaja Rosda Karya 
A, Wawan , Dewi M. (2010). Teori dan pengukuran Pengetahuan, Sikap dan Perilaku Manusia Yogyakarta : Nuha Medika.

Anharudin Azis. (2013). Pengaruh remunerasi terhadap kinerja pegawai di Kantor Pelayanan Pajak Pratama Tuban

Bambang Guritno dan waridin (2005) Guritno, Pengaruh Persepsi Karyawan Mengenai Perilaku Kepemimpinan, Kepuasan Kerja Dan Motivasi Terhadap Kinerja.JRBI. Vol 1. No 1. Hal: 63-74

Bangun, Wilson. (2012). Manajemen Sumber Daya Manusia, Erlangga, Bandung.

Budi. (2012). Pengaruh ompetensi, motivas, dan Kinerja Pegawai Negeri Sipil BPMPTSP Provinsi Kalimantan Barat

De Pora, Antonio. (2011). "Remunerasi (kompensasi \& benefit).” Jakarta: Rana Pustaka

Edy, Sutrisno. (2011). Manajemen Sumber Daya Manusia. Penerbit: Jakarta, Kencana

Hadari Nawawi. (2005). Penelitian Terapan.Yogyakarta:Gajah Mada University Press.

Hasibuan, Malayu S.P. (2012). MANAJEMEN: Dasar, Pengertian, dan Masalah. Jakarta: PT Aksara.

Hasibuan, Malayu S.P. (2006) Manajemen Dasar, Pengertian, dan Masalah,Edisi Revisi, Bumi Aksara:Jakarta

Mahmudi. (2015). Manajemen Kinerja Sektor Publik Edisi Kedua.Yogyakarta: UPP STIM YKPN

Mangkunegara, Anwar Prabu. (2011). Manajemen Sumber Daya Manusia Perusahaan, Remaja Rosda Karya: Bandung.

Mangkunegara, Anwar Prabu. (2014). Manajemen Sumber Daya Manusia Perusahaan, Remaja Rosda Karya: Bandung.

Moeheriono. (2014). Pengukuran Kinerja Berbasis Kompetensi. Bogor : Penerbit Ghalia Indonesia.

Mohamad Surya. (2004). Psikologi Pembelajaran dan Pengajaran. Bandung: Pustaka Bani Quraisy.

Pasolong, Harbani. (2010). Teori Administrasi Publik, Alfabeta, Bandung.

Robbins, P.Stephen dan Timothy A. Judge. (2012). Perilaku Organisasi. Salemba Empat. Jakarta

Sadili, Samsudin. (2006). Manajemen Sumber Daya Manusia. Bandung : Pustaka Setia
Simamora, Henry. (2004). Manajemen Sumber Daya Manusia. Edisi Kedua. Cetakan Kesembilan. Penerbit YKPN. Yogyakarta

Sudarmanto. (2009). Kinerja dan Pengembangan Kompetensi SDM (Teori, Dimensi Pengukuran dan Implementasi dalam Organisasi). Yogyakarta : Pustaka Pelajar

Suwatno, dan Tjutju Yuniarsih. (2013). Manajemen Sumber Daya Manusia. Bandung: Alfabeta.

Wibowo. 2011. Manajemen Kinerja. Jakarta: Raja Grafindo Persada

Yunita Sari Mustikaningsih dan Rini Handayani. 2014. "Pengaruh Gaya Kepemimpinan, Budaya Organisasi, Komitmen Organisasi Dan Remunerasi Terhadap Kinerja Karyawan". Media Ekonomi Dan Manajemen, Januari 2014, Vol. 29 No. 1, ISSN: 085-1442.

\section{Jurnal}

Indrawati. (2017). Pengaruh Kompetensi Terhadap Kinerja Pegawai Pada Kantor Pertanahan Kota Kendari

Niluh. (2018). Pengaruh Motivasi dan Komitmen Pegawai Negeri Sipil terhadap Kinerja Pegawai Negeri Sipil Di Dinas Kebudayaan Provinsi Bali

Putu. (2018). Pengaruh budaya, komitmen organisasi dan kompetensi terhadap OCB pada pegawai honorer Sekretariat Daerah Kota Denpasar

Salsabil. (2017). Pengaruh Etos kerja, disiplin kerja dan komitmen organisasi terhadap kinerja pegawai Kantor Kementrian Agama Kota Batu

Yuliarti. (2016). Pengaruh Etos kerja, disiplin kerja dan komitmen organisasi terhadap kinerja pegawai pada Dinas Perumahan dan Penataan Ruang Daerah Kabupaten Morowali 